statistischer M. K.: $\quad p^{\mathrm{AA}}=c_{\mathrm{A}}, \quad \alpha=0$,

Nahordnung: $\quad p^{\mathrm{AA}}<c_{\mathrm{A}}, \quad \alpha<0$,

Nahentmischung: $\quad p^{\mathrm{AA}}>c_{\mathrm{A}}, \quad \alpha>0$.

Bleibt bei einer Änderung der Nachbarschaftverhältnisse, d. h. bei einer Änderung des Nahordnungsparameters $\alpha$ um $\Delta \alpha$ die Gitterkonstante, und damit in erster Näherung das Austauschintegral $I$ konstant, so hat dies - wie eine kurze Rechnung zeigt - eine relative Änderung der Curie-Temperatur gemäß:

$$
\frac{\Delta T_{\mathrm{c}}}{T_{\mathrm{c}}}=\frac{1-c_{\mathrm{A}}}{c_{\mathrm{A}}} \Delta \alpha
$$

zur Folge. - Wir nehmen an, daß die bei $900{ }^{\circ} \mathrm{C}$ 120 Stunden lang geglühten Proben eine statistische Atomverteilung besitzen, und daher der an diesen Proben ermittelte Wert von $T_{\mathrm{c}}$ dem Nahordnungsparameter $\alpha=0$ entspricht. Aus den durch das Tempern der homogenisierten Proben hervorgerufenen relativen CuriePunkts-Änderungen $\Delta T_{\mathrm{c}}$ können demnach die Nahordnungsparameter der getemperten Proben nach Gl. (3) bestimmt werden. (Die Voraussetzung, daß die Gitterkonstante von den vorgenommenen Wärmebehandlungen unbeeinflußt bleibt, erscheint nach $\operatorname{CoLes}^{4}$ als erfüllt.)

\section{Diffusion of Indium in Lithium Metal}

\section{А. Отт}

Physics Department, Chalmers University of Technology, Gothenburg, Sweden

(Z. Naturforsch. 23 a, 2126-2127 [1968] ; received 14 October 1968)

The diffusion of $\mathrm{In}^{11 \mathrm{~m}}$ in lithium has been measured using a thin film plating and sectioning method, between $75^{\circ} \mathrm{C}$ and $170^{\circ} \mathrm{C}$.

The data fit the Arrhenius relation $D=D_{0} \exp (-Q / R T)$ where

$D_{0}=(0.39 \pm 0.25) \mathrm{cm}^{2} \cdot \mathrm{sec}^{-1}$ and $Q=(15.87 \pm 0.36) \mathrm{kcal} \cdot \mathrm{mol}^{-1}$.

The activation energy for In tracer diffusion in $\mathrm{Li}$ is by $3 \mathrm{kcal} \cdot \mathrm{mol}^{-1}$ higher than that for $\mathrm{Li}$ self-diffusion. This result is not in line with the common model of vacancies attracted by ions with excess valency, and thus presents a contrast to known observations of impurity diffusion in close packed metals.

The experimental method has been described elsewhere ${ }^{1}$. The In $^{114 m}$ was from New England Nuclear Corporation, checked with a multichannel analyzer and found to be free from radioactive impurities. The lithium was from Foote Lithium Corporation and had a purity of $3 \mathrm{~N} 5$.

\begin{tabular}{rc}
\hline$T\left({ }^{\circ} \mathrm{C}\right)$ & $D \cdot 10^{11}\left(\mathrm{~cm}^{2} / \mathrm{sec}\right)$ \\
\hline 171.5 & $663.7 \pm 21.2$ \\
16.05 & $402.8 \pm 13.4$ \\
151.0 & $242.8 \pm 8.2$ \\
138.6 & $132.7 \pm 4.8$ \\
117.4 & $58.59 \pm 2.2$ \\
107.2 & $27.57 \pm 0.80$ \\
75.5 & $4.50 \pm 0.15$ \\
\hline
\end{tabular}

Table 1.

Experimental results.

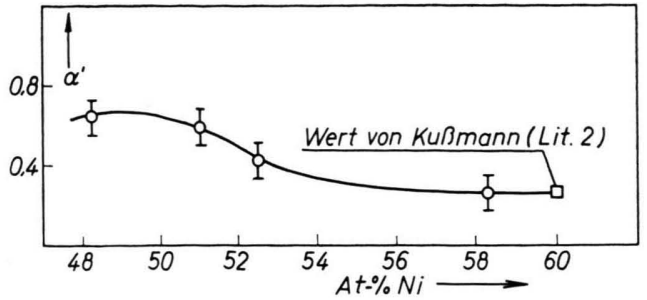

Abb. 2. Nahentmischungsparameter $\alpha^{\prime}$ nach 200-stdg. Tempern bei $380{ }^{\circ} \mathrm{C}$ (Ausgangszustand: homogenisiert).

In Abb. 2 ist der Verlauf des Nahordnungsparameters über der Konzentration dargestellt. Ob die Nahentmischung im Bereich von 50 : 50 At. $\%$ ein Maximum durchläuft oder mit zunehmendem $\mathrm{Cu}-\mathrm{Gehalt}$ weiter ansteigt, kann auf Grund der bisher durchgeführten Messungen nicht entschieden werden.

Den Herren Professoren Dr. F. LiHL und Dr. K. M. Косн danken wir für ihre freundliche Unterstützung.

${ }^{4}$ B. R. Coles, J. Inst. Metal. 84, 346 [1955/56].

The experimental values of the diffusion coefficient, $D$, are given in Table 1 and plotted in Fig. 1 , where the solid curve is a least squares fit of the experimental points.

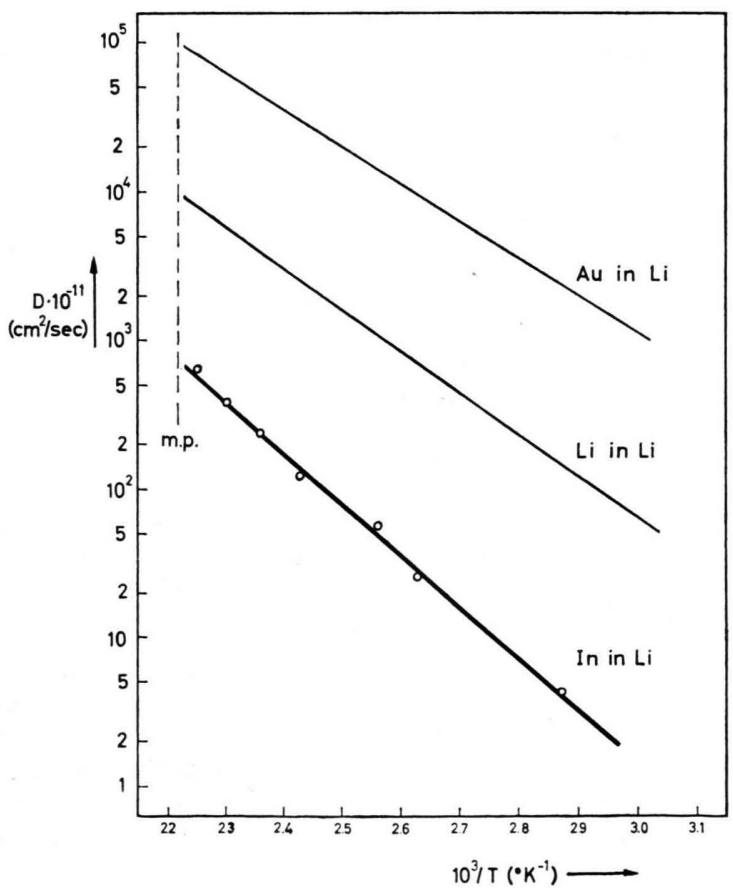

Fig. 1. Arrhenius plot of diffusion in lithium metal. The present work is here compared with the diffusion results for $\mathbf{A u}^{195}$ and $\mathrm{Li}^{6}$ tracers in $\mathrm{Li}$. 
In Fig. 1 we have also plotted the equation for the diffusion coefficient of $\mathrm{Au}$ in lithium ${ }^{2}$ and that for "self-diffusion" 3 (i. e. $\mathrm{Li}^{6}$-tracer in lithium).

The striking feature of Fig. 1 is the small diffusivity observed in the present work, as compared with the very rapid diffusion rate for the univalent tracer. This is in qualitative contradiction to electrostatic theories ${ }^{4,5}$ according to which a polyvalent impurity should tend to diffuse faster than an univalent one.

\begin{tabular}{lccc}
\hline & $D_{0}\left(\mathrm{~cm}^{2} \mathrm{sec}^{-1}\right)$ & $Q\left(\mathrm{kcal} \cdot \mathrm{mol}^{-1}\right)$ & Ref. \\
\hline $\mathrm{Li}$ in $\mathrm{Li}$ & $0.12 \pm 0.05$ & $12.62 \pm 0.21$ & 3 \\
$\mathrm{Au}$ in Li & $0.21 \pm 0.08$ & $10.99 \pm 0.18$ & 2 \\
$\mathrm{In}$ in Li & $0.39 \pm 0.25$ & $15.87 \pm 0.36$ & \\
\hline
\end{tabular}

Table 2. Impurity diffusion data in lithium.

According to recent evidence ${ }^{6}$ it is possible for certain impurities in polyvalent matrices to dissolve interstitially rather than substitutionally. The tendency for

1 J. N. Mundy, A. Ott, A. Lodding, and L. Löwenberg, to be published.

2 A. Отт, Z. Naturforsch., in press.

3 A. Ott, J. N. Mundy, L. Löwenberg, and A. Lodding, Z. Naturforsch. 23 a, 771 [1968]. partially interstititial solution is especially marked for univalent impurities while the tendency for substitutional solution grows with increasing valency.

In our experiment the low activation energy and high diffusion coefficient for $\mathrm{Au}$ in $\mathrm{Li}$ might well indicate an interstitial-like diffusion mechanism. The open structure of the alkali metals may favour this. The three-valent In tracer, on the other hand, may be dissolved mainly substitutionally and so diffuse by a slower mechanism. This work thus indicates that the diffusion mechanism in lithium might possibly depend on the solution mode.

On the other hand, the possibility of a highly relaxed vacancy mechanism does not appear to be completely ruled out. A polyvalent impurity, especially one with a large ionic radius, may tend to neutralise the net negative charge of the vacancy at the same time as it may fill the collective density deficit which defines the defect.

This research has been supported by the Swedish Council for Applied Research. I wish to acknowledge stimulating discussions with Docent A. Lodding and Dr. P. Thernquist.

${ }^{4}$ D. Lazarus, Phys. Rev. 93, 973 [1954].

5 A. D. LeClatre, Phil. Mag. 7, 141 [1962].

6 T. R. Anthony and D. Turnbull, Appl. Phys. Letters 8, 120 [1966].

\section{Heavy Isotopes of Protactinium}

\section{N.Trautmann*, R.Denig, N. Kaffrell, and G. Herrmann \\ Institut für Anorganische Chemie und Kernchemie der Universität Mainz, Germany}

(Z. Naturforsch. 23 a, 2127-2130 [1968]; received 15 October 1968)

We have identified a new isotope of protactinium, $2.3-\mathrm{min}{ }^{238} \mathrm{~Pa}$, in bombardments of ${ }^{238} \mathrm{U}$ with $14-\mathrm{MeV}$ neutrons and have investigated its decay properties. The nuclides 9.1-min ${ }^{237} \mathrm{~Pa}, 9.1-\mathrm{min}{ }^{236} \mathrm{~Pa}$ and $24-\mathrm{min}$ ${ }^{235} \mathrm{~Pa}$, produced by irradiations of uranium isotopes with $14-\mathrm{MeV}$ neutrons and $100-\mathrm{MeV}$ bremsstrahlung, were also studied since only scanty information on their properties has been published up to now.

Our results are summarized in this note. Discussions of the complex decay schemes have to be postponed until $\gamma-\gamma$ and $\beta-\gamma$ coincidence spectra are available. Unfortunately, the source strengths achieved by us so far made it impossible to apply coincidence techniques.

Experimental. The targets, all in the form of uranyl nitrate, consisted of $99.3 \%{ }^{238} \mathrm{U}$ (i. e. natural uranium), $99.8 \%{ }^{236} \mathrm{U}$ or $90 \%{ }^{235} \mathrm{U}$ plus $10 \%{ }^{238} \mathrm{U}$. Bombardments with 14-MeV neutrons from the T-D reaction were performed using the Cockcroft-Walton accelerator at this institute; fluxes up to $4 \cdot 10^{10}$ neutrons $/ \mathrm{cm}^{2} \mathrm{sec}$ were available. Irradiations in a bremsstrahlung spectrum of $100 \mathrm{MeV}$ endpoint energy were carried out at the Mainz electron linear accelerator.

\footnotetext{
* In part from a Dissertation, Mainz 1968.
}

The protactinium isotopes were radiochemically separated from the predominating fission-product activity by partition between diisobutylcarbinol and strong hydrochloric acid containing complex-forming agents ${ }^{1}$. Counting samples were prepared by coprecipitation with ferric hydroxide. The first count could be started within 3.5 to 4 minutes after the end of bombardment. Decontamination from short-lived fission products was tested using samples prepared by thermal-neutron irradiation of ${ }^{235} \mathrm{U}$ in the Mainz research reactor.

The $\gamma$-ray spectra of ${ }^{238} \mathrm{~Pa}$ and ${ }^{237} \mathrm{~Pa}$ were measured with $\mathrm{Ge}(\mathrm{Li})$ detectors, those of ${ }^{236} \mathrm{~Pa}$ and ${ }^{235} \mathrm{~Pa}$ with $\mathrm{NaI}(\mathrm{Tl})$ detectors. In addition, a $\gamma-\gamma$ sum spectrometer consisting of two $\mathrm{NaI}(\mathrm{Tl})$ crystals and an X-ray spectrometer with xenon proportional counter were used. Beta-ray spectra were obtained with plastic scintillators. Only approximate $\beta$-ray energies and intensities could be deduced for ${ }^{238} \mathrm{~Pa},{ }^{237} \mathrm{~Pa}$ and ${ }^{236} \mathrm{~Pa}$ since their spectra are rather complex.

Mass assignments. The $\beta$-decay curves of the protactinium fractions show, apart from small admixtures of expected long-lived nuclides, short-lived components of the half-lives and relative activities listed in Table 1. The $\gamma$-decay curves are similar except that the 24-min activity decreases sharply or disappears entirely. The 9.1-min components $\mathrm{A}$ and $\mathrm{B}$ are discernible by their $\gamma$-ray spectra.

Under the conditions used, the principal processes resulting in the formation of protactinium isotopes are

1 N. Trautmann, R. Denig, and G. Herrmann, to be published. 